\title{
The synthetic antimicrobial peptide 19-2.5 interacts with heparanase and heparan sulfate in murine sepsis in vivo and in human sepsis ex vivo
}

\author{
L Martin $^{1 *}$, S Doemming ${ }^{1}$, A Humbs ${ }^{1}$, L Heinbockel $^{2}$, K Brandenburg $^{2}$, G Marx', T Schürholz ${ }^{1}$ \\ From ESICM LIVES 2015 \\ Berlin, Germany. 3-7 October 2015
}

\section{Introduction}

Heparanase is an endo- $\beta$-glucuronidase that cleaves highly potent heparan sulfate (HS) from its proteoglycan, thereby triggering the inflammatory response in [1]. Thus, new anti-infective agents that interact with heparanase may be promising tools for sepsis therapy. As a novel anti-infective agent, peptide 19-2.5 (pep2.5) belongs to the class of synthetic anti-lipopolysaccharide peptides, however its activity is not restricted to Gramnegative bacterial infection $[2,3]$.

\section{Objectives}

To evaluate the interaction of pep2.5 with heparanase in murine sepsis in vivo and in human sepsis ex vivo.

\section{Methods}

First, we used a model of murine cecal ligature and puncture (CLP) sepsis to study the impact of pep2.5 on heparanase in vivo in 12 NMRI mice. Mice were treated with pep 2.5 or $\mathrm{NaCl} 0.9 \%$. Plasma was sampled $24 \mathrm{~h}$ after CLP. Second, we investigated whether pep2.5 interacts with heparanase in human plasma samples ex vivo. We added pep2.5 $(20 \mu \mathrm{g} / \mathrm{ml})$ to plasma of 18 septic shock patients according to the ACCP/SCCM definitions and to plasma of 10 healthy volunteers. Heparanase-levels, HS-levels and heparanase activity were measured using ELISA (AMS Biotechnology, Oxon, United Kingdom). All data are given as mean \pm standard deviation. A t-test with Holm-Š́ídák correction was used and a $\mathrm{p}$-value $<0.05$ was considered significant.

${ }^{1}$ Department of Intensive Care and Intermediate Care, University Hospital RWTH, Aachen, Germany

Full list of author information is available at the end of the article

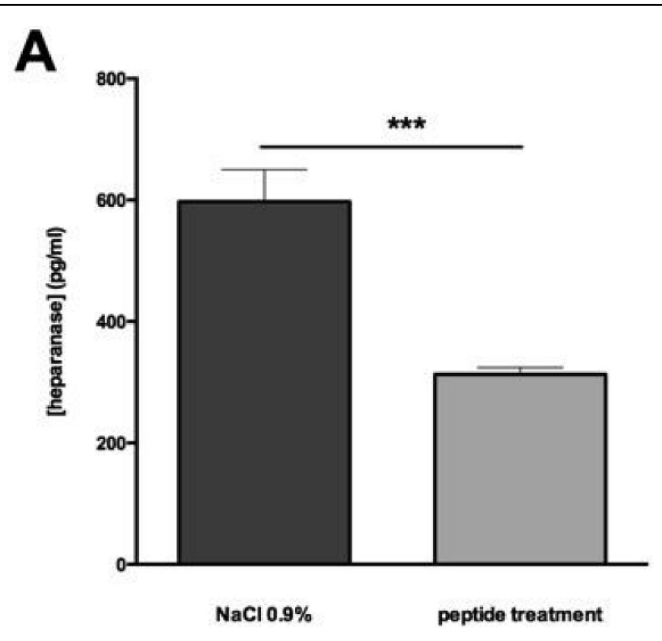

B

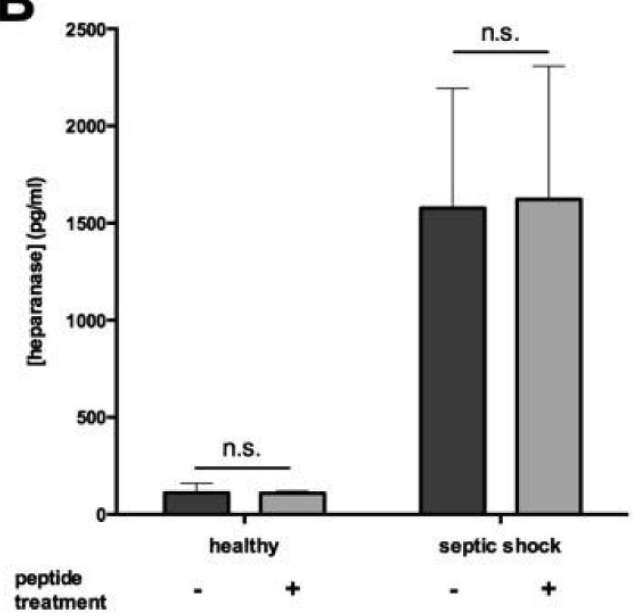

Figure 1 (A) Heparanase level in CLP-mice. (B) Heparanase level in human.* $p<0.05,{ }^{* *} p<0.005,{ }^{* * *} p<0.001$. 


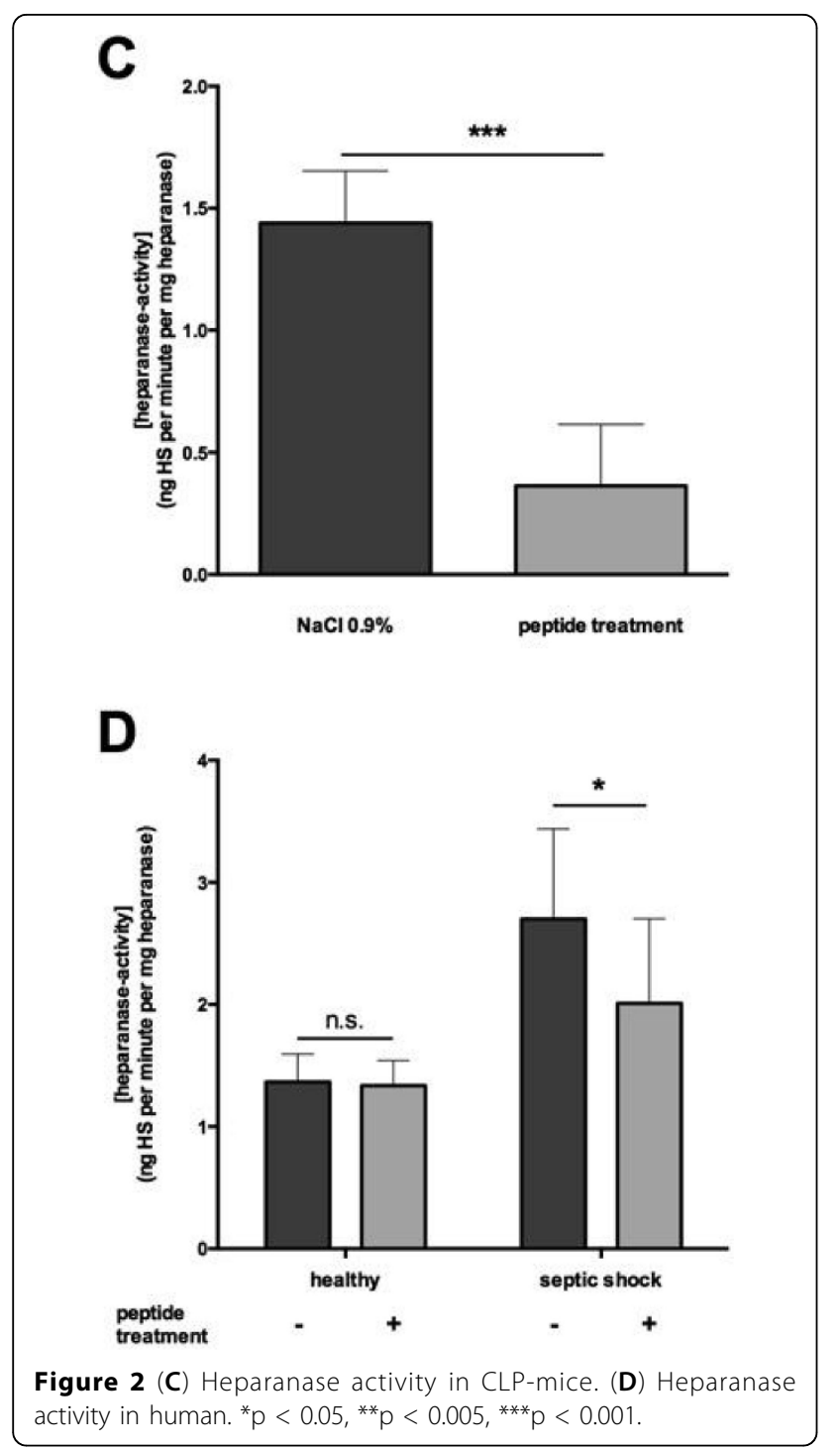

\section{Results}

Mice subjected to CLP without treatment displayed higher heparanase levels in plasma compared to mice treated with pep2.5 ( $\mathrm{p}<0.0001)$. Treatment with pep 2.5 resulted in lower heparanase activity $(\mathrm{p}<0.0001)$ and reduced HS-levels $(\mathrm{p}<0.0001)$, compared to untreated animals (Figure 1).

Septic shock patients $(78 \%$ male) were $70 \pm 15$ years old and healthy volunteers (50\% male) were $67 \pm 19$ years old. Plasma heparanase levels, heparanase activity and HS-levels were significantly higher in individuals with septic shock than in healthy individuals (all p < 0.0001 ). The ex vivo addition of pep2.5 did not impact heparanase levels, however heparanase activity and HSlevels were decreased by adding pep 2.5 to plasma of septic shock patients (all $\mathrm{p}<0.05$, Figure 1 ).
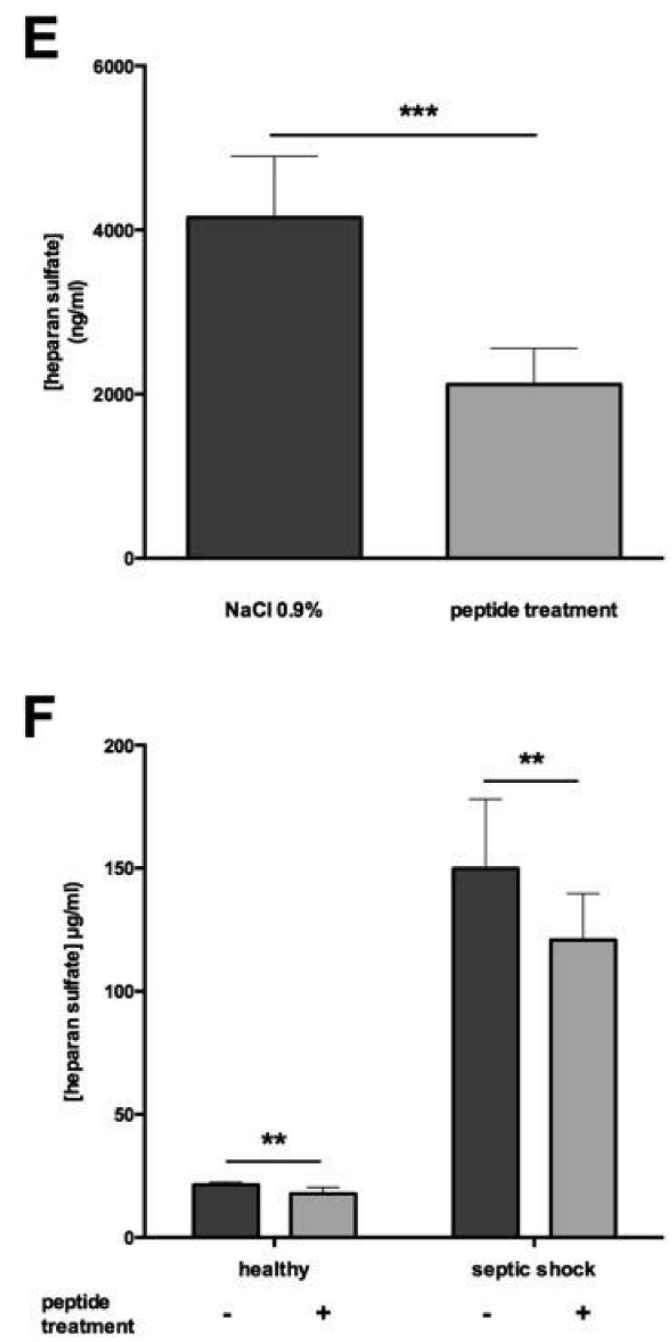

Figure 3 (E) Heparan sulfate level in CLP-mice. (F) Heparan sulfate level in human. ${ }^{*} p<0.05,{ }^{* *} p<0.005,{ }^{* *} p<0.001$.

\section{Conclusions}

The synthetic antimicrobial peptide 19-2.5 interacts with heparanase in human and murine sepsis and reduces levels of highly potent HS. Thus, peptide 19-2.5 may have the potential for further development as a new anti-infective drug in sepsis therapy.

\section{Grant Acknowledgment}

This work was supported by an intramural grant to Dr. Lukas Martin (START 693900).

\section{Authors' details}

'Department of Intensive Care and Intermediate Care, University Hospital RWTH, Aachen, Germany. ${ }^{2}$ Division of Biophysics, Forschungszentrum,

Borstel, Germany.

Published: 1 October 2015 


\section{References}

1. Goodall K, Poon IKH, Phipps S, Hulett MD: Soluble Heparan Sulfate Fragments Generated by Heparanase Trigger the Release of ProInflammatory Cytokines through TLR-4. PLoS One 2014, 9(1):e109596.

2. Heinbockel L, Sánchez-Gómez S, Martinez de Tejada G, Dömming S, Brandenburg J, Kaconis Y, et al: Antimicrob Agents Chemother 2013, 57(3):1480-1487.

3. Gutsmann T, Razquin-Olazarán I, Kowalski I, Kaconis Y, Howe J, Bartels R, et al: New antiseptic peptides to protects against endotoxin-mediated shock. Antimicrob Agents Chemother 2010, 54(9):3817-3824.

doi:10.1186/2197-425X-3-S1-A516

Cite this article as: Martin et al.: The synthetic antimicrobial peptide 192.5 interacts with heparanase and heparan sulfate in murine sepsis in vivo and in human sepsis ex vivo. Intensive Care Medicine Experimental 2015 3(Suppl 1):A516.

\section{Submit your manuscript to a SpringerOpen ${ }^{\circ}$ journal and benefit from:}

- Convenient online submission

- Rigorous peer review

- Immediate publication on acceptance

- Open access: articles freely available online

- High visibility within the field

- Retaining the copyright to your article

Submit your next manuscript at $\gg$ springeropen.com 